\title{
ЧЕРЕДОВАНИЕ О/А В КОРНЯХ ВТОРИЧНЫХ ИМПЕРФЕКТИВОВ
}

\author{
Айсылу САгитовА \\ Казанский федеральный университет
}

\section{АннотАция}

Чередование $о / a$ в основах глаголов несовершенного вида является грамматическим средством, как правило сопровождающим образование имперфективов с суффиксом -ива- (-ыва-) на современном этапе развития русского языка (обусловливать - обуславливать). Однако эта закономерность действует не для всех вторичных имперфективов: охватывая основную часть глаголов, это чередование не возникает, однако, в таких формах, как приурочивать, узаконивать и др., и вызывает сложности в выборе форм в случаях типа обезболивать/обезбаливать, уполномочивать/уполномачивать. Основной задачей настоящей статьи является выявление условий и причин возникновения вариативности во вторичных имперфективах, а также факторов, способствующих сохранению корневого о на разных этапах истории русского языка. Статья состоит из двух частей: в первой части рассматривается история возникновения и развития чередования o/a. Теоретические выкладки сопоставляются с данными, полученными из Словаря русского языка XI-XVII вв. Во второй части рассматривается чередование о/а во вторичных имперфективах на современном этапе развития языка. Первый подраздел посвящен изучению восприятия чередования носителями языка. Метод исследования - анкетирование позволяет выявить причины, мотивирующие выбор одной из форм. Во втором разделе изучается употребление форм с о и $a$ в корне в языке художественной и нехудожественной литературы. Метод - статистический: анализируются количественные данные, полученные из Национального корпуса русского языка. В конце статьи приводятся выводы - обозначаются факторы, влияющие на судьбу чередования.

\section{[1] ИСТОРИЯ ЧЕРЕДОВАНИЯ}

Исследуемое чередование $о / a$ восходит к древнейшим чередованиям краткого и долгого гласных: носити - нашати, просити - прашати. Первоначально оно использовалось для выражения длительности и повторяемости действия. Этот $a$ был отмечен в старейшем типе кратных глаголов, который «характеризовался суффиксом -а- или -ја- и удлинением коренного гласного» (Обнорский 2009, 54). Указанный тип сложился еще в индоевропейскую эпоху. 


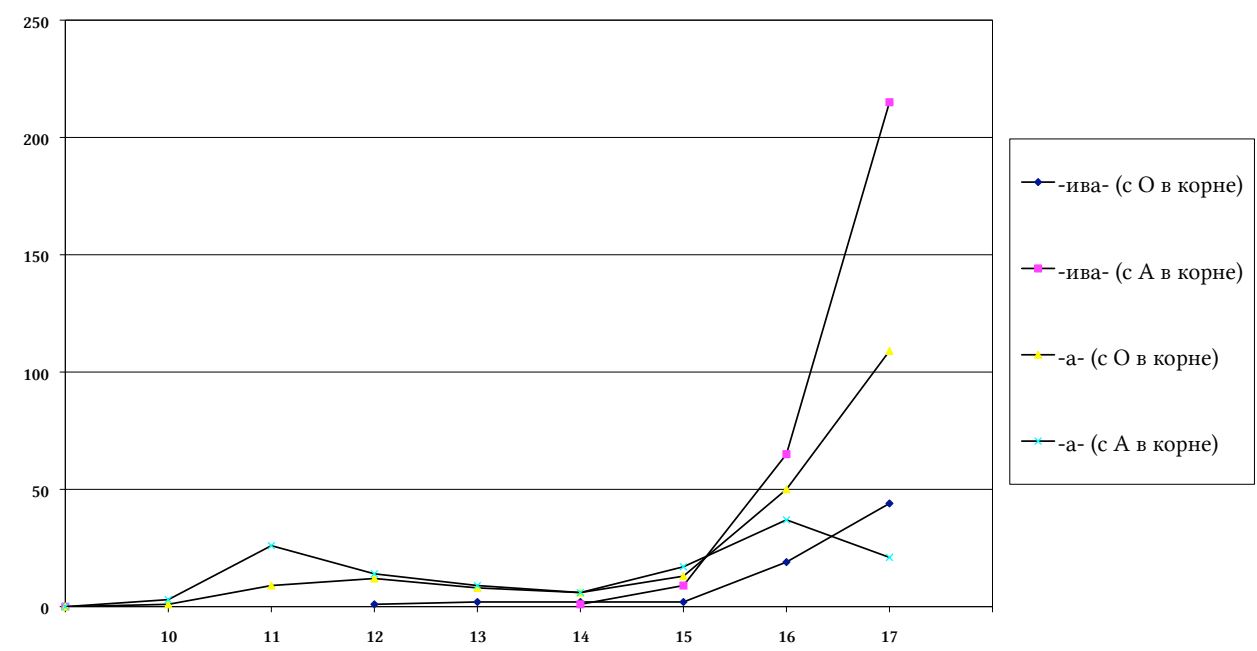

Рис. 1: Количество форм, зафиксированных в Словаре XI-XVII вв.

В производных имперфективах с суф. -ја- это чередование сохранилось и в XI в. было весьма продуктивным. Так, в Словаре русского языка XI-XVII вв. ${ }^{1}$ зафиксировано 35 глаголов несовершенного вида с суффиксом -а-, встречающихся в памятниках XI в., при этом 26 из них имеют в корне гласный $a$. B XIII$\mathrm{XIV}$ вв. начала действовать тенденция к устранению чередования o/a - происходило выравнивание основ. Вполне закономерно, что этот период характеризуется увеличением форм с о в корне. Так, в Словаре русского языка XI-XVII вв. отмечено практически равное количество глаголов с $о$ и $a$ в корне $(14 \mathrm{c} о$ и $15 \mathrm{c} a)$. К этому времени получает распространение новый тип образований на -ивать, -ывать. В 13-14 вв. в СРЯ XI-XVII он зафиксирован исключительно с о в корне. Отмечен только один глагол с $a$ : «А тобъ, г(о)с(поди)не, кн(я)з(ь) вел(икии, без насъ) не доканчивати ни с кимъ... Дух.и дог.гр., 11, ое.1351» (СРЯ XI-XVII , т. 4, 290). B XVI-XVII вв. картина кардинально меняется. Количество форм с о в корне в первичных имперфективах (т.е. с суффиксами -а-, -ја-) существенно увеличивается. Это связано с тем, что вариантность глагольных основ уже была чисто орфографической и не отражала реального произношения этих глаголов, т.к. «в XV-XVI вв. на обширных территориях русских диалектов распространяется аканье» (Историческая 1982, 187). В связи с тем что у большей части имперфективов ударенным был суффикс, корневой о оказался на акающих территориях в предударной позиции и стал произноситься как $a$ - «появилось несоответствие между складывавшейся орфографической нормой, предпола-

[1] Материал получен в результате сплошной выборки из 16 томов Словаря русского языка XXI-XVII веков. Далее в тексте - в СРЯ XI-XVII . 
гавшей написание о в имперфективах, и реальным произношением ее как [а]» (Историческая 1982, 187).

Из 341 зафиксированного в СРЯ XI-XVII примера с первичными имперфективами 208 (т.е. 60,9\%) - с о в корне. С приближением к современности количество их увеличивалось и постепенно полностью вытеснило первичные имперфективы с корневым $a$. Орфографическая норма современного литературного языка сохранила чередование лишь в корреляциях -лаг-/-лож-, устранив его у остальных глаголов и закрепив написание о в целях унификации орфографического облика корневой морфемы.

Иначе обстоит дело со вторичными имперфективами. В старорусский период (XVI-XVII вв.) суф. -ива- входит в «стадию максимальной продуктивности» (Историческая 1982, 176). При этом увеличивается количество вторичных имперфективов с чередованием в корне. Из 360 примеров 290 - с $а$ в корне (80,55\%): «Да во всъхъ селахъ и деревняхъ монастырскихъ крестьяномъ межъ себя дворовъ не огнаивати, и хоромы имъ въ тьхх мұхсто, которые обътшаютъ, новые хоромы и городьба городити. Уставн. Гр. Патр. Иова, 19. 1590» (СРЯ XIXVII , т. 12, 238), «Да и впредь [мои складники] похваляются всякими недобрыми дъълы... и скотъ нашъ побивать, и за пасву выганивать. АХУ II, 665. 1623 г.» (CPЯ XI-XVII , т. 3, 192). Несомненно, это чередование уже не является фонетическим, как раньше, но является показателем несовершенного вида. Оно не обозначает долготу или краткость гласного, однако, на наш взгляд, с его помощью передается значение длительности, которое заключается теперь в категории несовершенного вида. В толковом словаре отмечается, что «-ыва-(ть) - формообразовательная единица, образующая формы несовершенного вида глагоЛОВ СО ЗНАЧЕНИЕМ ДЛИТЕЛЬНОСТИ ИЛИ ДЛИТЕЛЬНОЙ ПОВТОРЯЕМОСТИ ДЕЙсТВИЯ» (Ефремова 2000, 461). Подробнее о соотношении длительности и совершенности/несовершенности можно прочитать в работах Г. Павского (Павский 1850), А. Потебни (Потебня 1977), С. Никифорова (Никифоров 1952) и др.

На современном этапе развития языка мена звуков происходит уже и там, где первоначально подобного чередования быть не могло (растамаживать, озабачивать) - по аналогии в этот круг втягиваются все новые и новые глаголы. Таким образом, основной функцией чередования становится создание четкой оппозиции «совершенный вид - несовершенный вид», происходит его морфологизация. Итак, чередование о/а в корнях глаголов прошло следующие этапы:

1) чередование восходит к старым чередованиям краткого и долгого гласного;

2) с появлением суффиикса -ыва-(-ива-) гласный $а$ характеризовал новый тип глаголов;

3) по аналогии с глаголами, уже принявшими новую форму, чередование начало происходить там, где его быть не должно было: формы с $a$ «допускаются 


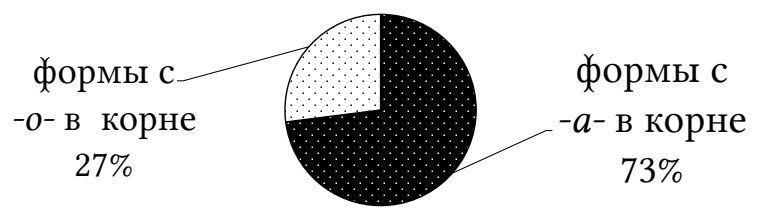

рис. 2: Соотношение форм в разговорном языке

и там, где их не следовало бы употреблять» (Чернышев 1915, 275), а новые слова, которые входят в употребление, «принимают сразу форму с [а], минуя стадию варьирования» (Горбачевич 1978, 164);

4) охватив большинство глаголов, рассматриваемое чередование наряду с суффиксом -ива- стало восприниматься как способ противопоставления совершенного и несовершенного видов.

\section{[2] ЧЕРЕДОВАНИЕ О/А В СОВРЕМЕННОМ РУССКОМ ЯЗЫКЕ}

В глаголах с суффиксом -ива-(-ыьва-) чередование o/a в основе осталось продуктивным в современном русском языке. Наибольшее распространение оно получило в XIX-XX вв., однако процесс мены $о$ на $a$ еще не завершился.

Еще А. Х. Востоковым было отмечено, что «ежели в коренном слоге глагола есть гласная о без ударения, то оная, пред окончанием ывалъ или ивалъ, принимая на себя ударение, превращается в $a »$, в противном случае «коренная $o$ остается без перемены» (Востоков 1835, 63). Но если в начале XIX в. это правило имело лишь несколько исключений - по Востокову: страивал (от строить), палзывал (от ползать), дабривать (при с-, у-добрить), вворачивать (от ворочать), то в конце XIX столетия в группе с $о$ ударным уже употребляются «большей частию образования с ударяемым $a \gg$ (Чернышев 1915,156 ).

В XX в. ситуация становится еще более разнородной. Так, С. П. Обнорский, Д. Э. Розенталь, Л. К. Граудина, отмечают, что глаголы делятся на две группы: к первой группе относятся «глаголы совершенного вида с ударением на корневом $0<\ldots>$ ко второй - с ударением не на корневом $o$. В глаголах второй группы $<\ldots>$ корневое о всегда переходит в ударяемое а (выработать - выраба́тывать); сложнее дело обстоит с глаголами первой группы, так как для них нет единого правила образования формы несов. вида с корневым о или а» (Розенталь 1965, 174).

Действительно, глаголы, совершенный вид которых имеет в корне ударное $o$, в настоящее время могут вести себя по-разному:

- закрепиться с а в корне: настроить - настраивать, затронуть - затрагивать; 
- сохранять в корне исконный гласный: узаконить - узаконивать, подытожить - подытоживать;

- употребляться как с о, так и с $а$ в корне: обусловить - обусловливать и обуславливать, обезболить - обезболивать и обезбаливать.

Наибольший интерес для нас представляют 2 последние группы - так называемые вариативные формы и формы с $о$ в корне.

Вариативность - это промежуточный этап в развитии языка, так как абсолютно идентичные формы не могут долго сосуществовать, и одна из них рано или поздно выйдет из употребления либо приобретет стилистическую маркированность. Так, нормативными, литературными долгое время считались формы с $о$ в корне: «варианты с - $a$ - свойственны разговорной речи, варианты с -oболее употребительны в письменной, книжной и деловой речи... Если в письменных стилях зарегистрированы оба типа вариантов, часто с преимущественным употреблением вариантов на -о-, то в устной речи предпочитают формы с - $a$-» (Граудина 1980, 220); «новые варианты с корневым [а] чаще встречаются в тех печатных жанрах, которые менее строго опекаются корректорами» (Горбачевич 1978, 163).

Постепенно сначала в разговорную, затем в письменную, литературную норму проникают глаголы с - $a$ - в корне. В XIX и нач. XX в., по свидетельству К. С. Горбачевича, формы с гласным - $a$ - в корне запрещались в статьях и брошюpax, посвященных изложению «неправильностей русского языка», но «после работы С. П. Обнорского (2009) стало характерным стилистическое разграничение (формы с $о$ - в строгой литературной речи, формы с $a-$ в разговорной речи), положение вариантов с $a$ в нормативной шкале оценок продолжает оставаться неопределенным» (Горбачевич 1978, 163).

Основной задачей нашего исследования является определение положения вариантов с $a$ в нормативной шкале оценок для современного этапа развития языка.

\section{[2.1] Чередование о/а в представлении носителей русского языка}

Живое и продуктивное в настоящее время чередование корневых $o / a$ во вторичных имперфективах является очагом ослабленной нормы. Выбор одной из форм для этих форм часто бывает затруднен даже для носителей русского языка. Методом исследования восприятия форм с $o$ и $a$ в корне этой категорией лиц был выбран опрос. Необходимо учитывать, что в ответах будет отражаться не реальная речевая практика респондента, а его представление о том, как надо говорить, - представление, которое может расходиться с его собственной речевой практикой. На материале Обратного словаря (Зализняк 2003), а также Словаря современного русского литературного языка (Словарь СРЛЯ 1946-1965) был составлен наиболее полный список глаголов (171), в которых чередование 
начало происходить с XVIII века или еще не произошло - тех, которые в совершенном виде имеют о ударное в корне. Они входят в группу глаголов, для которых «нет единого правила образования формы несов. вида с корневым о или а» ${ }^{2}$ (Розенталь 1965, 174). Из них были отобраны глаголы для опросного листа: отбор был произведен таким образом, чтобы в опросник вошли слова как нейтральные, так и отмеченные в словарях как устаревшие, официальные, специальные. В итоге был составлен список из 52 глаголов с пропусками на месте корневого гласного. Респондентам необходимо было вставить тот гласный, который они обычно употребляют в речи. В опросе приняли участие 100 человек, из них

- 25 человек - ученики 10-11 классов;

- 25 человек - студенты-филологи;

- 25 человек - студенты-«не филологи»;

- 25 человек - работающие (старше 40 лет).

Первые две группы составили в основном люди, хорошо владеющие грамматическими правилами и кодифицированными нормами: предполагалось, что ученики помнят школьное правило, требующее чередования в корне при суффиксе -ивать (-bьвать), за исключением некоторых слов: обусловливать, опорочивать, подытоживать и др. Студенты-филологи, с одной стороны, помнят школьное правило: «Правописание безударного гласного нельзя <..> проверять при помощи глаголов несовершенного вида с суффиксами -ывать, -ивать, так как в этих глаголах вместо корневого о часто бывает $а$. Например, слово выбросить следует проверять словом бросить, а не выбрасывать» (Греков 2003, 61), с другой - стремятся вычленить корневую морфему и восстановить исходную форму слова. Третью и четвертую группы составили респонденты, которые в силу отдаленности от филологии их специализаций употребляют вариативные формы интуитивно.

Первые три группы респондентов противопоставлены по возрастной категории последней группе (работающие), что является принципиальным фак-

[2] Более подробную информацию о зависимости гласного о/а в корне глагола несовершенного вида от ударного/неударного гласного в корне слова - в работах А. Востокова, В. Чернышева, Л. Граудиной. 
тором в вопросе определения нормы. ${ }^{3}$ В речи людей старшего поколения, как правило, отражаются нормы более консервативные, устойчивые, в речи младшего - более мобильные, гибкие.

При анализе результатов опроса были учтены все вышеперечисленные факторы. Итак, в ответах преобладали формы с $а$ в корне - 73\%, формы с о составили 27\%. Самой многочисленной оказалась группа из 27 глаголов, где респонденты практически единогласно выбрали формы с $а$. Это слова, в которых колебания не фиксируются ни в современных словарях, ни в разговорной речи, т.к. процесс мены $о$ на $a$ в корне рассматриваемых глаголов завершился уже в XIX в. или начале XX века: благоустраивать, доканчивать, достраивать, заготавливать, замораживать, застраивать, наготавливать, настраивать, облагораживать, обмораживать, обстраивать, осваивать, оспаривать, перестраивать, подстраивать, потрагивать, устраивать, приготавливать, присваивать, пристраивать, прорабатывать, разрабатывать, расстраивать, сдваивать, удваивать, укорачивать, усваивать, успокаивать. Можно выделить группу слов, где форма с о кажется искусственной, т.к. она не зафиксирована в словарях и не употребляется в устной речи, но достаточно большое количество респондентов выбрали именно ее: заболачивать (61) - заболочивать (35), задабривать (63) - задобривать (37), обихаживать (68) - обихоживать (31), утраивать (69) - утроивать (31), сдабривать (45) - сдобривать (55), сосредотачивать (68) - сосредоточивать (32), удабривать(47) - удобривать (50), удостаивать (72) - удостоивать (28), уславливаться (51) - условливаться (48). Надо заметить, что основной процент голосов за форму о в отмеченной выше группе набирается за счёт выбора, сделанного школьниками, и, вопреки нашим ожиданиям, студентами нефилологических специальностей. Названные респонденты стремятся проверить глаголы, вызывающие затруднения, с помощью родственных слов: заболочивать - болото (четверо опрошенных затруднились сделать выбор гласного в корне, мотивировав это тем, что первый раз видят это слово. Таким образом, можно предположить, что редко употребляемое и потому не всем знакомое слово вызывает потребность подобрать к нему ряд однокоренных слов и, соответственно,

[3] В культуре речи учитываются законы не только современного литературного языка, но и различных языковых подсистем (Фомина 2007, 50):

a) территориальные и социальные варианты языка - литературный язык

б) диахронические особенности - синхронические особенности

в) литературный стиль произношения - разговорный стиль произношения

г) собственно русская лексика - заимствованная лексика

В рамках нашей работы рассматриваются подсистемы (б) и (в). 
проверить его) $)^{4}:$ задобривать, сдобривать - добрый, обихоживать - обиход (два человека воздержались), утраивать - трое (!), сосредоточивать - средоточие, точный (!), удостоивать - достоин, условливаться - условие. Даже по этим немногочисленным примерам видно, что респонденты в первую очередь пытаются подобрать проверочное слово, однако не всегда удачно. Но стремление проверить, соотнести с рядом однокоренных слов, тем более если слово вызывает сомнения в плане его лексического значения, поддерживает произношение и написание $о$ в корне. Таким образом, одним из факторов, удерживающих о в корне, может выступать стремление к сохранению единого орфографического облика корневой морфемы, особенно в малоупотребительных словах. Гласный о удерживается в тех случаях, когда ощущается четкая связь глагола с прозводящей основой. Особенно явно это происходит в конфиксальных образованиях. Гласный в корне сохраняет свое качество, т.к. производное слово мотивируется именем с $o$ (в нашем случае) в корне, особенно это характерно для многочисленных образований с конфиксом обез...ивать и словообразовательным значением 'лишать того, о чем говорится в производящей основе': обездоливать, обеспложивать, обезболивать и т.п. Но даже в этих случаях формы с $a$ начинают активно использоваться. Так, вариант обезбаливать выбрали $23 \%$ (почти четверть) опрошенных.

Дольше удерживается о в корне в тех случаях, когда конфиксальное образование сопровождается большим количеством родственных слов с аналогичным гласным в корне. К.С. Горбачевич, приводя в пример глагол сосредоточивать, этот фактор (количество однокоренных слов) называет «авторитетом орфографии и словообразовательного гнезда» (Горбачевич 1971, 164). Особенно действенным, на наш взгляд, был этот фактор в древнерусском и старорусском языке. Наши наблюдения показывают, что словообразовательные гнезда для исследуемых глаголов в эти периоды были шире по сравнению с современным, что, несомненно, также способствовало сохранению корневого гласного. Так, например, для глагола изгоняти/изганяти в Словаре русского языка 11-17 вв. отмечены следующие однокоренные слова: изгон, изгона, изгонение, изгоненый, изгонка, изгонникъ, изгонный, изгономъ, изгоняя и др.

Не последнюю роль в выборе гласного в корне играет фоноэстетический момент - благозвучие формы. Действительно, в последние годы стал признаваться психолингвистический фактор: при отборе варианта произношения как нормы носители языка оценивают его с эстетической и стилистической точки зрения. Л.А. Вербицкая в качестве важного обстоятельства отмечает престижность той или иной формы, того или иного варианта произношения. Многие респонденты мотивировали свой выбор тем, что «с $a$ некрасиво», «так благозвучнее». Как неблагозвучные могут расцениваться и формы, типа облагоро-

[4] Данные получены из опросного листа. Респондентам предоставлялась возможность объяснить выбор словоформы. 
живать, успокочвать (то есть архаизированные), озабачивать, опорачивать, nриурачивать. «Некрасивые», с точки зрения носителей языка, формы нередко используются в целях достижения комического эффекта современными юмористами, например: «Меня опорачивали другие», - из номера на юбилейном вечере Клары Новиковой (Первый канал ТВ, 15 декабря 2006), особенно если они вызывают нежелательную омонимию: «Нефть в России, как всегда, просрачивается» (Михаил Задорнов). Нами отмечены неоднократные случаи исправления говорящим одной из форм глагола и ее замены на «менее неблагозвучную». Это касается глаголов просрочивать/nросрачивать, проспоривать/npoспаривать - формы с $а$ в этих случаях вызывают нежелательные ассоциации со словами, имеющими отрицательную коннотацию. Выбор форм глаголов варьируется и в зависимости от возраста и рода занятий носителей языка, а также, что наиболее важно, от характера самого глагола.

Речь людей старшего поколения, несомненно, более консервативна, поэтому в ответах группы людей от 40 лет преобладают формы с о в корне. В ответах школьников также отмечено преимущество вариантов с о в корне, что связано со стремлением респондентов подобрать проверочное слово.

Справедливости ради надо отметить, что однокоренные слова в большей или меньшей степени пытались подобрать все категории опрошенных. Это связано с немаловажной тенденцией: если носителями языка сохраняется и ощущается связь глагола с однокоренными словами, производящей основой, то в этом случае удерживается о в корне. Как удалось выяснить, связь со словообразовательным гнездом поддерживается в отыменных образованиях, особенно конфиксальных. Необходимость выявления производящей основы возрастает в том случае, когда слово не знакомо носителю языка, но в основе его лежит известное, но малоупотребительное слово (например, глагол унавоживать). С другой стороны, если подбор производящего слова вызывает затруднения (например, из-за чередования согласных, сопровождающего чередование о/а в корне: заболачивать, обихаживать), то нередко выбор делается в пользу формы с $a$ в корне. При неверной мотивации глагола выбор гласного зависит от того слова, которым глагол был мотивирован. Например, глагол огорошивать соотносится говорящими со словом горох, что поддерживает корневой о. Исконный о также сохраняется в глаголах, которые могут вызывать нежелательную омонимию (просрочивать, проспоривать). Таким образом, можно выделить общую тенденцию к росту употребления форм с $а$. Ей противостоит ряд причин, преимущественно словообразовательного характера, который поддерживает традиционный облик слов и обусловливает удержание о на фонетическом и орфографическом уровне. 
[2.2] Чередование о/а в языке художественной и нехудожественной литераmypbl

В результате сплошной выборки из Грамматического словаря русского языка (Зализняк 2003) были выявлены вторичные имперфективы, образованные от форм с о в корне. По данным Национального корпуса русского языка ${ }^{5}$ и библиотеки Максима Мошкова ${ }^{6}$ была составлена таблица статистических данных употребления найденных в словаре Зализняка глаголов, что позволило нам выделить 4 группы:

1) глаголы, малоупотребительные как в форме совершенного, так и несовершенного вида;

2) глаголы, употребительные преимущественно в форме совершенного вида;

3) глаголы, употребительные преимущественно в форме несовершенного вида;

4) глаголы, широко употребляющиеся как в форме совершенного, так и несовершенного вида.

Для исследования употребления глаголов в современных текстах художественной и нехудожественной литературы (1991-2011 гг.) был использован Национальный корпус русского языка.

ПЕРвУю группу составляют глаголы, малоупотребительные или не зафиксированные в письменных текстах ${ }^{7}$ вообще как в форме совершенного, так и несовершенного вида. Эти формы зафиксированы в словаре Зализняка, но практически не встречаются в текстах (по данным Национального корпуса).

Малоупотребительными они являются по разным причинам:

1) узкоспециализированные слова: наканифоливать, обезуглероживать, обеспложивать, обессоливать, перефасонивать, притонивать, растаможивать, присворивать;

2) разговорно-сниженная лексика: засупонивать, отшпандоривать, nогоготьвать, раздраконивать, разлимонивать, распатронивать, ухоливать;

3) разговорная лексика: натопьвать, обмозоливать, обрезонивать, обхлопьвать, присаливать, прочколивать, прочтопьвать, раззнакомливать, разохочивать, рассиропливать;

4) советизм: орабочивать;

[5] http://www.ruscorpora.ru

[6] http://aot.ru

[7] Здесь и далее речь идет о художественных произведениях, использованных в электронных источниках. 
5) устаревшая лексика: прихоливать;

6) диалектные слова: обигоривать.

Узкоспециализированные слова, или термины, являются «законсервированными» в своем употреблении и редко проникают в обыденную речь. Поэтому и норма здесь изменяется в последнюю очередь.

Устаревшее слово прихоливать, советизм орабочивать уже вышли из употребления, диалектизм обигоривать также не фиксируется в современных словарях, поэтому в дальнейшем не представляется целесообразным вести о них разговор. Глаголы, вошедшие в группу разговорной лексики, малоупотребительны в письменном языке не только потому, что они маркированы и их использование, например, в языке художественной литературы, в научной литературе нежелательно, но и потому, что они малоупотребительны даже внутри своей группы - в разговорной речи. Таким образом, очевидно явное вытеснение исследуемых форм, хотя единичные глаголы встречаются вплоть до настоящего времени:

(1) Люди раззнакомливаются, уезжают, исчезают, умирают или забывают друг о друге, теряют интерес, перестают звонить... [Катанян Василий. Лиля Брик. Жизнь (1999)] .

Итак, вся группа является «изолированной» в том смысле, что из-за малой употребительности отмеченных лексем кажется невозможным изменение в ней произносительной нормы, тем более проникновение вариантов с $a$ в корне глаголов несовершенного вида в литературный язык.

вторую группу составляют глаголы, употребляемые преимущественно в форме совершенного вида. Можно выделить несколько причин такого употребления:

1) В самой семантике глагола может содержаться нацеленность на результат: благоустраивать - 'хорошо оборудовать, делать удобным для жизни, работы, приводить в порядок (о месте проживания, работы и т.п.)'. Конечная цель оговаривается уже в лексическом значении слова. Подобными являются глаголы доканчивать, докрашивать (от крошить), доспоривать, досаливать (в первом значении $)^{8}$, задабривать, настраивать, опошливать, разохочивать, разрознивать:

[8] досаливать несов. перех.

1. Заканчивать соление чего-л.

2. Солить до определенного предела.

3. Солить дополнительно 
(2) Поверит, несомненно, водителю, но меня хочет задобрить, чтобы я не верещала и не создавала ему проблем. [Татьяна Устинова. Подруга особого назначения (2003)].

(3) Не в столь еще давние времена по большим теплым праздникам, в пасху и Троицу, задабривали его угощением, которое горкой складывали у корня и которое потом собаки же, конечно, и подбирали, но считалось: надо, не то листвень может обидеться. [Игорь Сухих. Однажды была земля // «Звезда», 2002].

Сюда вошли также формы с префиксом до- (финитивный, или окончательный способ действия) (Русская грамматика 1980, 598):

(4) Воевать стало не с кем, и он ушел их догонять - в надежде доспорить. [Дмитрий Быков. Орфография (2002)].

(5) Мы все еще доспариваем споры XX века, хотя видим и понимаем, что мир своим развитием оставил эти споры позади. [Александр Яковлев. Омут памяти. Т.2 (2001)].

2) Можно выделить глаголы, исключающие значение процессуальности, протяженности во времени, - действие в этих случаях происходит за относительно короткий промежуток времени: заспоривать (в значении «начать спорить», отмеченном в словаре Даля), растревоживать, обездоливать:

(6) - Видишь, как дело-то повернулось, не только твоего отца, он многих обездолил... [Марина Дяченко, Сергей Дяченко. Магам можно все (2001)].

(7) Основная идея концепции «устойчивого развития» заключается в организации общества таким образом, чтобы не наносить необратимого ущерба природной среде и не обездоливать последующие поколения людей в отношении необходимых для них жизненных ресурсов. [Сергей Ткачев. Устойчивое развитие: Спасение человечества или «троянский конь»? (2003) // «Наш современник», 2003.06.15].

3) Особняком стоит группа глаголов, где указанные формы несовершенного вида малоупотребительны, т.к. их заменили более краткие и, следовательно, более удобные в употреблении, абсолютно идентичные в лексическом плане формы несовершенного вида: намозоливать - мозолить, скомкивать - комкать, сморщивать - морщить, опошливать - опошлять, оформливать оформлять ${ }^{9}:$

[9] В последних двух случаях представлены примеры замены суфффикса -ива- на - $a$ - 
(8) Порывы ветра то пропускали, то скомкивали и уносили прочь далекий низкий звук дизеля. [Василий Голованов. Остров, или оправдание бессмысленных путешествий (2002)].

(9) Он заикался, сипел, комкал бланки в дрожащих руках, беспомощно пятился, когда Инка предлагала ему еловый чай, напиток, сулящий долгую жизнь, полную побед. [Улья Нова. Инка (2004)].

Подобная синонимия форм, писал В.В. Виноградов, возникает в тех случаях, когда реальное значение предлога сливается с конкретным значением глагола и поглощается им. Например: скопить - скапливать - копить. «Этот процесс чаще завершается вытеснением предложной формы несовершенного вида» (Виноградов 2001, 511), что обусловлено, на наш взгляд, столь распространенной в языке, особенно в последнее время, тенденцией к экономии языковых средств.

Таким образом, перед нами группа глаголов, по разным причинам употребляющихся в совершенном виде, а это значит, что при использовании несовершенного вида этих глаголов, в сознании говорящего возникает форма совершенного вида, и гласная в корне совершенного вида оказывает непосредственное влияние на выбор гласной в форме вида несовершенного: «употребляя в несовершенном виде форму с о, мы подчиняем влиянию форм совершенного вида: заработывать - заработать, настроивать - настроить)» (Чернышев 1915, 269).

Но даже в представленных случаях со столь ярким взаимодействием форм совершенного и несовершенного вида влияние одной формы не абсолютно. Значимыми оказываются и словообразовательные факторы.

18 глаголов из 51 (зашторивать, обездоливать, объегоривать, отфутболивать, оформливать, потопывать, потрогивать, похлопывать, поцокивать, почмокивать, пропесочивать, проспоривать, просрочивать, раздраконивать, разрознивать, растревоживать, скомкивать, ухлопывать), действительно, имеют в корне $o$, но сохранение этого гласного объясняется совокупностью факторов: влияние глаголов совершенного вида и словообразовательные факторы.

Так, в глаголе обездоливать о в корне удерживается за счет конфикса обез...ивать (ср. обезвоживать, обезболивать, обеспложивать и др.). Слова заuторивать, отфутболивать являются производными от заимствованных существительных штора, футбол. Именно иноязычный характер этих слов может, по нашему мнению, удерживать о в корне.

В глаголах похлопьвать, поцокивать, почмокивать также можно выделить конфикс, но не меньшее значение в этом случае имеет характер корня - звукоподражательные слова хлоп, цок, чмок, которые могут считаться дополнительным фактором, удерживающим $о$, т.к. в сознании носителей языка такие слова воспринимаются как нечленимое целое, в котором нежелательны, а в изолированном употреблении (имеется ввиду использование чисто звукоподража- 
тельных слов, а не производных от них) и вовсе невозможны какие бы то ни было изменения.

Можно выделить группу слов с ярко выраженной экспрессивной окраской, имеющих просторечный характер: раздраконивать, пропесочивать, объегоривать, которые ассоциируются с существительными дракон, песок, егор, но уже не мотивируются ими. Тем не менее о в этих словах также сохраняется - видимо, в связи с просторечным характером этих слов и редким употреблением их в речи.

(10) Обслуживающему персоналу русские опять же удобны и приятны: они их спокойно объегоривают, наливая в ванны вместо воды из природных источников обычную горячую воду с добавлением солей. [Олег Oceтинский. Из Москвы в Прагу - с любовью. Часть II (2002) // «Известия», 2002.11.22].

(11) Там на собраниях так пропесочивали - на всю жизнь запоминалось. [Елена Костина. Кто в ответе за ребенка? (2001) // «Семья», 2001.11.14].

В глаголе просрочивать, как уже отмечалось выше, о сохраняется во избежание нежелательных ассоциаций, хотя отмечен единичный случай употребления формы с $a$, но несколько ранее обсуждаемого периода:

(12) Он просрачивает ссуды в кредитные товарищества. [Юрий Фельштинский. Разгром левой оппозиции в СССР; Письма ссыльных большевиков (1928)] .

Нет оснований утверждать, что форма просрачивать не закрепится в языке, т.к. случаи ее употребления, особенно в разговорной речи, уже фиксируются. К тому же эта форма отмечена в словарях, пока с пометой «неправильно». Как писал В. Матезиус, «развитие языков вообще складывается прежде всего из изменений, которые вначале с точки зрения действующей нормы воспринимаются как ошибки» (Ицкович 1970, 15). Естественно запрещается то, что уже встречается в узусе, входит в употребление, а вследствие этого - и в поле зрения грамматиста.

Оставшиеся глаголы по разным причинам, оговоренным выше, являются малоупотребительными и поэтому, как и слова первой группы, не могут быть гибкими по отношению к литературной норме.

В трЕтью группу входят глаголы, с преимущественным употреблением форм несовершенного вида: выспаривать, обезболивать, обихаживать, облагораживать, оспаривать, охорашивать, подзадоривать, прирабатывать, притопьвать, прихорашивать, причмокивать

Преимущественное употребление этих форм в несовершенном виде свидетельствует о дополнительной семантике длительности (обихаживать, прихора- 
шивать) или многократности (причмокивать). Только 4 глагола из представленного списка сохраняют в корне о: обезболивать, подзадоривать, npumonbватb, причмокивать. Причины такого употребления частично были оговорены выше: обезболивать - конфикс обез...ивать удерживает гласный в корне; $n p u$ топывать, причмокивать - звукоподражательный характер производящей основы + конфикс при...u(bl)вать; подзадоривать - конфиксальное образование.

В остальных случаях в корне наблюдается «долгий» гласный $a$.

ЧЕТВЕРТУю ГрУПпУ составляют глаголы, для которых нельзя выделить приоритет одной из видовых форм. Именно в них обнаруживается колебание форм с а и о в корне (обусловливать/обуславливать, приурочивать/приурачивать, унавоживать/унаваживать и т.п.). Они находятся в некотором промежуточном состоянии при общем процессе мены $о$ на $a$ - некоторые стилистически маркированы (сосредотачивать - разг.), другие считаются неправильными (уполномачивать), есть и равноправные варианты (обусло/авливать). Важно учесть, что на глаголы действуют разнонаправленные силы - удерживающие $o$, с одной стороны, и провоцирующие мену на $a-$ с другой. В том случае, когда факторы, удерживающие о, более значительны (например, связь с производящей основой), чередование затруднено, например, уполномочивать. Надо отметить, что в художественной литературе отмечено единичное употребление глаголов этой группы: обусло/авливать - 9, сосредото/ачивать - 8, уполномо/ачивать - 4, приурочивать - 3 и т.д. В то время как в нехудожественной литературе (публицистика, научно-учебная литература и т.д.) эти глаголы широко используются: обусловливать (502) - обуславливать (121), сосредоточивать (45) - сосредотачивать (22). При этом если в публицистике для этих глаголов количество форм с о составляет 63\%, то в научно-учебной литературе - 76\% (сосредоточивать) и $86 \%$ (обусловливать).

Язык научно-учебной литературы более консервативен, тогда как другие сферы употребления языка (особенно публицистика) постепенно сближаются с разговорной речью, где преобладают формы с $a$. Если в XIX веке этой особенностью отличались лишь некоторые жанры (очерки, мемуары, драматургия), то сейчас использование вариантов с а достаточно свободно практически во всех жанрах. Это связано с тем, что на современном этапе развития языка происходит их смешение.

В старорусском и древнерусском языке ситуация представляется более разноплановой. На первый взгляд не прослеживается закономерности употребления того или иного гласного в зависимости от жанра: в одном памятнике могут встречаться формы как с $a$, так и с о в корне. Например, в Вестях-Курантах (XVII в.) отмечено 12 интересующих нас форм с суффиксом -ива-, из них 6 форм - с $a$ в корне, 6 - с о. То же - в памятниках XVI века - Домострое, Назирателе, Требнике и др. 
Однако в памятниках деловой письменности - различных грамотах, делах, актах - зафиксированы в основном формы с $a$ в корне, тогда как в религиозной литературе - преимущественно о. Необходимо отметить, что в памятниках духовной литературы формы с суффиксом -ива- вообще встречаются редко - предпочтительнее здесь был суффикс -а-.

B XV в. о в корне отмечен в Палее Толковой, Неизданном памятнике русского церковного права XII в., и в сборнике Муханова - сборнике документальных материалов по истории России, Литвы, Украины, Белоруссии и Польши XIV - XVIII вв. Гласный $a$ в корне - в Актах, относящихся до юридического быта древней России, Исследованиях о Двинских грамотах, Памятниках дипломатических сношений Московского государства с Польско-Литовским государством и др. памятниках делопроизводства.

Таким образом, для предыдущих периодов закономерность, связанная с жанровыми особенностями текстов, прослеживается, но этот вопрос требует более детального изучения.

Одно несомненно: с каждым десятилетием, с каждым годом формы с $a$ в корне все увереннее проникают в литературу, не являясь уже в большинстве своем неправильными или ненормативными.

\section{[3] Выводы}

Процесс мены $о$ на $a$, начавшись с довольного узкого круга глаголов, к современному этапу развития языка набирает обороты, вовлекая все больше и больше глаголов. Распространению имперфективов с $a$ в корне способствует влияние следующих форм (фактор аналогии):

- слов, где $а$ в корне уже закрепилось (успокаивать, приспосабливать);

- слов, где чередования никогда не происходило (рассаживать, показывать) - по В. И. Чернышеву.

Гласный о в корне удерживает стремление к сохранению первоначальной формы, связь с однокоренными словами. Как было отмечено многими исследователями и подтверждается практическим материалом, $о$ дольше сохраняется в глаголах, совершенный вид которых имеет это о ударным - это глаголы, где выбор гласного зачастую вызывает колебания. Сохранение исконного гласного, по нашим наблюдениям, поддерживается следующими факторами, выявленными в [2.1]:

1. Четкая связь производного глагола с производящей основой, что, в свою очередь, может быть обусловлено следующими причинами: 
а) отыменным образованием этих глаголов: производящая основа может быть существительным (узаконивать), прилагательным (задабривать), числительным (удваивать), местоимением (присваивать) - в последних трех случаях, хотя уже и закрепились формы с $a$, но долгое время функционировали с о в корне;

б) наличием звукоподражательного слова в производящей основе (поцокивать, причмокивать);

в) отнесенностью к конфиксальным образованиям: в этом случае словообразовательное значение (абстрактно) и лексическое (более конкретно) указывают на слово, лежащее в производящей основе. Например, обез...ивать - 'лишать того, о чем говорится в производящей основе'; обезвоживать 'удалять из чего-нибудь воду’ (Ожегов \& Шведова 1999, 388);

г) наличием заимствованного слова в основе (отфутболивать, обандероливать);

2. Разветвленное словообразовательное гнездо, большое количество однокоренных слов с о в корне (сосредоточивать);

3. Возможность возникновения нежелательной омонимии (просрочивать). Закономерно, что а скорее возникает в тех случаях, где глаголы, теряют связь с производящей основой, например:

а) из-за чередования согласных на стыке корневой морфемы и суффиксальной, которым обычно сопровождается чередование о/а (заболачивать);

б) если глагол выступает в несвойственном для него значении (nomanblвать).

Исследование чередования в письменных текстах Национального корпуса русского языка позволило подтвердить значимость вышеназванных факторов, а также установить зависимость от сферы и широты употребления глагола. Так, в малоупотребительных глаголах норма, как правило, меняется очень медленно, либо не меняется вообще, если слово выходит из употребления. Редко употребительными словами считаются:

- архаизмы (прихоливать);

- историзмы (орабочивать);

- термины (обезуглероживать);

- просторечные слова (распатронивать); 
- устаревшие формы на -ивать, замененные формой на -ать, -ять (ускоривать).

На один и тот же глагол действует, как правило, несколько факторов и часто разнонаправленных. В этом случае на корневой гласный влияет не столько количество факторов, сколько их значимость. Так, например, глагол унавоживать - отыменной, образован от существительного навоз конфиксальным способом, но сам по себе этот глагол, по свидетельству С. П. Обнорского, «не городской», поэтому здесь нельзя говорить о строгом соблюдении нормы, что обусловливает распространение формы унаваживать, к тому же из-за наличия чередования з/ж, а также из-за «незнакомости» слова для городских жителей теряется связь с производящей основой, что также поддерживает форму с $a$.

Итак, отмеченная в начале статьи морфологизация чередования о/а во вторичных имперфективах способствует закреплению форм с $a$ в корне как средство противопоставления совершенного и несовершенного видов, что интуитивно осознается носителями языка. Статистические данные, полученные из Национального корпуса русского языка, показывают, что чем «свободнее» жанр, тем более свободно употребляются формы с $a$ в корне. Таким образом, нам представляется закономерной скорая стабилизация форм с $a$ в корне даже в тех словах, где сейчас она может казаться маловероятной. Мы же являемся свидетелями того, как эта норма складывается.

\section{СПИСОК ЛИТЕРАТУРЫ}

Вербицкая Л. А. Русская орфоэпия (к проблеме экспериментально-фонетического исследования особенностей современной произносительной нормы). Л.: Изд-во Ленингр. ун-та, 1976. 124 с.

Виноградов В.В.Видовой и продуктивный тип видовой корреляции того же происхождения // Виноградов В. В. Русский язык (Грамматическое учение о слове) / Под ред. Г. А. Золотовой. 4-е изд. М.: Русский язык, 2001. 718 с.

Винокур Г. О. Культура языка. изд. 2-е испр. и доп. М.: Федерация, 1929. 336 с.

Востоков А.Х. Изменение гласных пред окончанием многократного вида // Сокращенная русская грамматика А. Востокова. 3-е изд. СПб, 1835. 118с.

Горбачевич К. С. Изменение норм русского литературного языка. Л.: Просвещение, Ленингр. отделение, 1971. 270 с.

Горбачевич К. С. Морфонологические и суффиксальные варианты / Вариантность слова и языковая норма. Л.: Наука, Ленингр. отд-ние, 1978. 238 с.

Граудина Л.К. Вопросы нормализации русского языка: грамматика и варианты. М.: Наука, 1980. 288 с. 
Греков В.Ф. Пособие для занятий по русскому языку в старших классах/ В. Ф. Греков, С.Е. Крючков, Л. А. Чешко. 40-е изд. М.: Просвещение. 286 с.

Историческая грамматика русского языка: Морфология: Глагол / Под ред. Р. И. Аванесова, В. В. Иванова. М.: Наука, 1982. 440 с.

Ицкович В.А.Норма и ее кодификация // Актуальные проблемы культуры речи. Под ред. В. Г. Костомарова и Л. И. Скворцова. М.: Наука, 1970. с. 9-39.

Обнорский С.П. Очерки по морфологии русского глагола / Отв. редактор В. И. Борковский. Изд. 2-е. - М.: Книжный дом «Јиброком», 2009. - 248 с.

Никифоров С.Д. Глагол, его категории и формы в русской письменности II половины XVI в. / М.: Изд-во АН СССР, 1952. 344 с.

Павский Г. Филологические наблюдения над составом русского языка Г. Павского. Рассуждение ІІІ. О глаголе. 2-е изд. СПб., 1850. 238 с.

Потебня А.А. Из записок по русской грамматике. Том IV Вып.II Глагол. М.: Просвещение, 1977. 406 с.

Розенталь Д. Э. Практическая стилистика русского языка [Учебное пособие для вузов] М.: Высшая школа, 1965. 355с.

Фомина Т. Г. Современный русский язык. Фонетика: учеб. пособ. Казань: Казанский государственный университет, 2007. - 112 с.

Чернышев В.И. Правильность и чистота русской речи. Опыт русской стилистической грамматики. 2-е изд. Выпуск II, Части речи. СПб., 1915. 402 с.

\section{СЛОВАРИ}

Ефремова Т. Ф. Новый словарь русского языка. Толково-словообразовательный в 2 томах. Т.1 А - О М.: Рус. яз. Библиотека словарей русского языка, 2000. $1210 \mathrm{c}$.

Словарь современного русского литературного языка в 17 томах. М.-Л.: Изд. AH CCCP, 1948-1965.

Зализняк А. А. Грамматический словарь русского языка: Словоизменение / 4-е изд. испр. и доп. М.: Рус. словари, 2003. 794 с.

Словарь русского языка XI-XVII вв. T.1-16. М.: Наука, 1975-1990. 
Ожегов С.И. и Шведова Н. Ю. Толковый словарь русского языка: 80000 слов и фразеологических выражений / Российская академия наук. Институт русского языка и языкознания им. В.В. Виноградова. - 4-е изд., дополненное. М.: Азбуковник, 1999. - 944 с.

Шведова Н. Ю. Русская грамматика. т. 1-2. М: Наука, 1980.

АДРЕС АВТОРА

Айсылу Сагитова

Казанский федеральный университет

Россия

afsagitova@gmail.com 